ISSN 0258-7122

Bangladesh J. Agril. Res. 37(4): 729-736, December 2012

\title{
EFFECT OF DIFFERENT PACKAGING SYSTEMS AND CHLORINATION ON THE QUALITY AND SHELF LIFE OF GREEN CHILI
}

\author{
MOHAMMAD MIZANUR RAHMAN ${ }^{1}$, MD. MIARUDDIN ${ }^{2}$ \\ MD. GOLAM FERDOUS CHOWDHURY ${ }^{3}$, \\ MD. HAFIZUL HAQUE KHAN ${ }^{4}$ AND M.A. MATIN ${ }^{5}$
}

\begin{abstract}
The experiment was conducted to evaluate the effect of packaging materials on the quality and shelf life of green chili (Capsicum annuum) using passive modification of modified atmosphere packaging system. The modified atmosphere was created by making perforation in the polypropylene packets. Green chili pre-treated with chlorine water and then packaging in $0.3 \%$ perforated polypropylene packet resulted substantial reduction of weight loss and rotting/shriveling. These treatment combinations also considerably retained vitamin $C, B$-carotene, moisture content, etc. Under this condition the retention of quality and shelf life of green chili could be extended up to 10 days at ambient condition as compared to non-treated and without packaging.
\end{abstract}

Keywords: Packaging systems, chlorinations, shelft life, green chili.

\section{Introduction}

The total spices and condiments production in Bangladesh is about 1370 thousand metric tons from 729 thousand acres of land in 2007-2008 in which the production of chili is 118 thousand metric tons from 231 thousand acres of land (BBS, 2008). A large quantity of these spices is lost due to lack of proper postharvest handling, transportation, packaging, and storage facilities. The postharvest loss of vegetables in the developing countries is $20-50 \%$ and $5-25 \%$ in the developed countries (Amiruzzaman, 2000). Since green chili is highly perishable like other green vegetables, these are also subject to huge losses during the peak production season mainly during transportation, storage, and marketing.

In the super market, the shelf life of green chili has been found to be very short. The suppliers generally use gunny bags, big cartoons or boxes for carrying of green chili. The super market authority stored the collected chilies in different chambers of their cold room. They maintain the temperature at around $20^{\circ} \mathrm{C}$ but they do not maintain the humidity. As a result, the quality of green chilies

\footnotetext{
${ }^{1}$ Senior Scientific Officer, ${ }^{2}$ Principal Scientific Officer, ${ }^{3 \& 4}$ Senior Scientific Officer, Postharvest Technology Division, Bangladesh Agricultural Research Institute (BARI), ${ }^{5}$ Principal Scientific Officer, Agricultural Economics Division, BARI, Gazipur, Bangladesh.
} 
deteriorates quickly. Modified atmosphere packaging is used in storage of fresh fruits and vegetables; the term refers to their storage in plastic films, which restrict the transmission of respiratory gases. This results in the accumulation of carbon dioxide and depletion of oxygen around the crop, which may increase their storage life (Kader et al., 1989). Badgujar et al. (1987) reported that packing of brinjal in perforated polyethylene bags (1\% holes) prolonged shelf life and maintained quality compared to unpacked ones. The storage of green chili in small packet with or without some pretreatments and controlling its humidity may extend the shelf life. Pretreatments of vegetables with potassium permanganate water or chlorine water before packaging exhibit better shelf life in room temperature (Giraldo et al., 1977). Pretreatment is done in order to reduce micro flora, especially bacteria from the produce. Again, the demand of the consumers is only half to one kilogram of fruits and vegetables. However, there is no standard packet of such quantity. Standardization of packages will extend the shelf life of chilies as well as reduce the postharvest losses.

\section{Materials and Method}

Freshly harvested green chili (Capsicum annuum) was collected from the producers' field. The green chilies were sorted out to remove the pest affected, over matured and damaged ones in the laboratory of Postharvest Technology Division, BARI, Gazipur. Then, the green chilies were washed with chlorine water. Chlorine water is achieved by adding $200 \mathrm{ppm}$ sodium hypochlorite (or 2 Halotab tablets/litre water) in clean water (Amiruzzaman, 2000). Polypropylene of thickness 33 micron was used as packaging material and the packages were modified with different perforations $(0.1 \%, 0.2 \%, 0.3 \%$, and $0.4 \%$ perforation) to restrict the respiration of the chilies.

\section{Treatments}

$\mathrm{T}_{1}=$ Polypropylene packet with zero perforation,

$\mathrm{T}_{2}=$ Polypropylene packet with $0.1 \%$ perforation,

$\mathrm{T}_{3}=$ Polypropylene packet with $0.2 \%$ perforation,

$\mathrm{T}_{4}=$ Polypropylene packet with $0.3 \%$ perforation,

$\mathrm{T}_{5}=$ Polypropylene packet with $0.4 \%$ perforation,

$\mathrm{T}_{6}=$ Control (without packet),

The experiment was laid out in CRD with three replications. Each replication of the treatments consisted of 500 grams of green chilies. After packing, the chilies were stored in ambient temperature. Temperature and humidity were recorded and close observations were made to record the physicochemical parameters like moisture content, rotting/decay, marketability, vitamin $\mathrm{C}$ and Bcarotene of the green chili. 
Package perforation (\%): The perforations on the packets were made by using a puncher machine. The number of perforations on each packet was determined using the following calculation:

Area of each packet $=28 \mathrm{~cm} \times 26 \mathrm{~cm}=728 \mathrm{sq} \mathrm{cm}$

Diameter of each hole (dia. of puncher rod) $=0.4 \mathrm{~cm}$

From these data numbers of perforations were calculated to be 5, 10, 15 and 20 for $0.1,0.2,0.3$ and $0.4 \%$ perforation, respectively.

Shelf life (day): Shelf life of the green chilies was determined by observing and judging the quality parameters like rotting, shriveling, incidence of disease, etc. with respect to storage days. It was detected when most of the chilies of a treatment were still marketable.

Decay/Rotting (\%): It is the percentage of the damaged chilies. It was also determined by the quality parameters of the chilies like rotting, shriveling, incidence of disease, etc.

Physico-chemical analysis: Vitamin $C, \beta$-carotene and moisture content were determined for the fresh chilies at $7^{\text {th }}$ to $12^{\text {th }}$ days of storage. Vitamin $C$ (ascorbic acid) was determined by 2,6 - Dichlorophenol - Indophenol Visual Titration method, ß-carotene by AOAC (Association of Official Analytical Chemists) method and moisture content by Oven Drying method. These methods were conducted according to Ranganna (1986).

\section{Results and Discussion}

Data on physico-chemical parameters (moisture content, vitamin C, and Bcarotene) and rotting/decay as well as marketability of green chilies were analyzed at $7^{\text {th }}, 8^{\text {th }}, 9^{\text {th }}, 10^{\text {th }}, 11^{\text {th }}$, and $12^{\text {th }}$ days of storage at ambient temperature. Temperature was recorded during the experiment as $28^{\circ}-32^{\circ} \mathrm{C}$ (max.) and $20^{\circ}-$ $25^{\circ} \mathrm{C}$ (min.). Again, humidity was recorded as $65 \%-85 \%$ (at 9:00 am) and $68 \%$ $92 \%$ (at $4: 30 \mathrm{pm})$.

The results showed that green chili packed in $0.3 \%$ perforated packets $\left(\mathrm{T}_{4}\right)$ retained optimum moisture content $(77.18 \%)$, minimum rotting/decay $(23.56 \%)$ and thus highest marketability $(70 \%)$ followed by packet with $0.4 \%$ perforation $\left(\mathrm{T}_{5}\right)$ after 10 days of storage period (Fig. 1, 2, and 3). Retention of maximum moisture content $(80.94 \%)$ and maximum rotting/decay $(81.76 \%)$ occurred in the treatment $\mathrm{T}_{1}$ (sealed polypropylene) followed by treatment $\mathrm{T}_{2}(0.1 \%$ perforation) and $\mathrm{T}_{3}(0.2 \%$ perforation), respectively, through the storage periods (Fig. $1 \& 2$ ). Conservation of excessive moisture content resulted more condensed water in the $\mathrm{T}_{1}$ packet thus enhanced the rotting. Chilies kept in bulk without packaging (treatment $\mathrm{T}_{6}$ ) lost moisture drastically and shriveled rapidly thus lost marketable quality as turned into red and lost freshness. After 10 days of storage, the green 
chilies stored in $0.3 \%$ perforated packets $\left(\mathrm{T}_{4}\right)$ showed best acceptance as compared to other treatments in terms of freshness, rotting/decay and turning into red that ultimately led its highest marketability. The storage of the chilies in the polypropylene packets conserved the moisture hence prevented shrinkage and reduced the weight loss. Chilies in the perforated packets lost moisture with respect to perforated openings but slower than the bulk and open storage. Respiration involves the oxidative breakdown of complex substrate molecules, normally present in plant cells such as starch, sugars and organic acids to simpler molecules, in the course of which energy, carbon dioxide and water are given out. Atmospheres low in $\mathrm{O}_{2}(1-5 \%)$ and high in $\mathrm{CO}_{2}(5-10 \%)$ have been used to extend the shelf-life of fresh-cut fruits and vegetables by reducing respiration, product transpiration and ethylene production, as $\mathrm{O}_{2}$ is involved in the conversion of 1-amino-cycloprane-1-carboxylic acid to ethylene (Yang and Hoffman, 1984). In general, an inverse relationship has been shown between respiration rates of fruits and vegetables and their postharvest shelf-life. Reduced $\mathrm{O}_{2}$ and high $\mathrm{CO}_{2}$ levels have also been proved to effectively control enzymatic browning, firmness and decay of fresh-cut fruits and vegetables. Besides, the proliferation of aerobic spoilage microorganisms can be substantially delayed with reduced $\mathrm{O}_{2}$ levels (Alejandra Rojas-Grau et al., 2009).

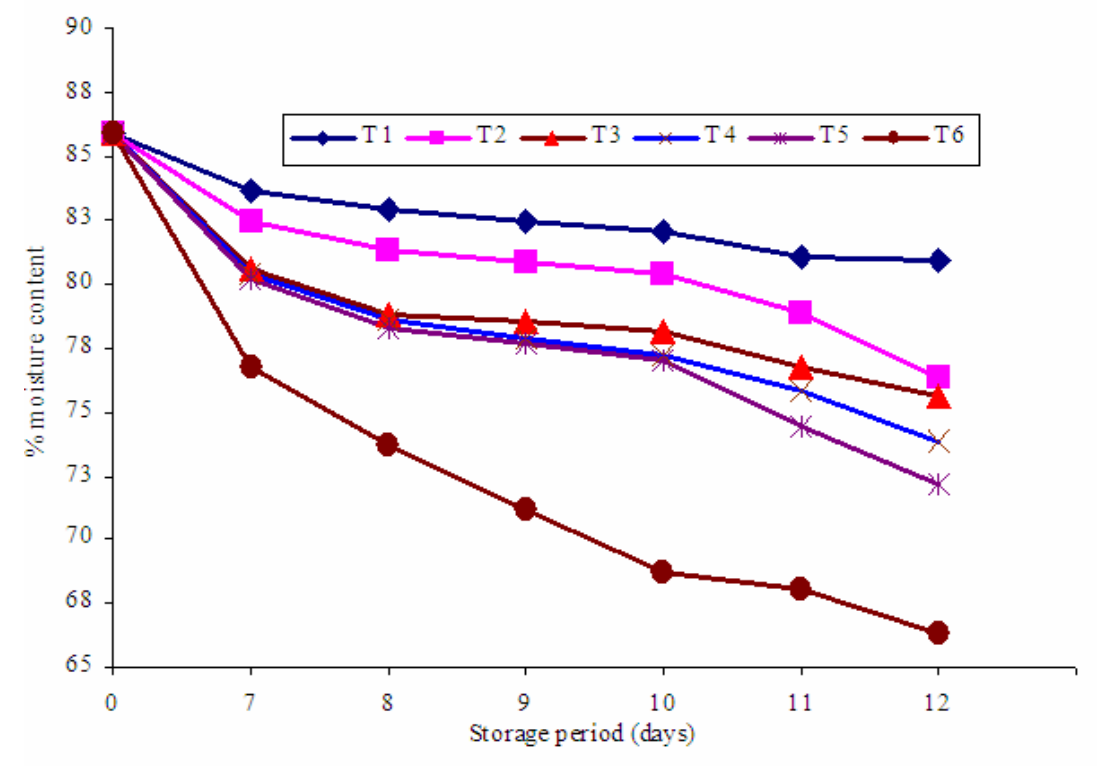

$\mathrm{T}_{1}=$ Zero perforation packet $\mathrm{T}_{2}=0.1 \%$ perforation packet, $\mathrm{T}_{3}=0.2 \%$ perforation packet, $\mathrm{T}_{4}=0.3 \%$ perforation packet, $\mathrm{T}_{5}=0.4 \%$ perforation packet, $\mathrm{T}_{6}=$ Control (without packet)

Fig.1. Effect of different packaging systems on the moisture content of green chili during storage. 


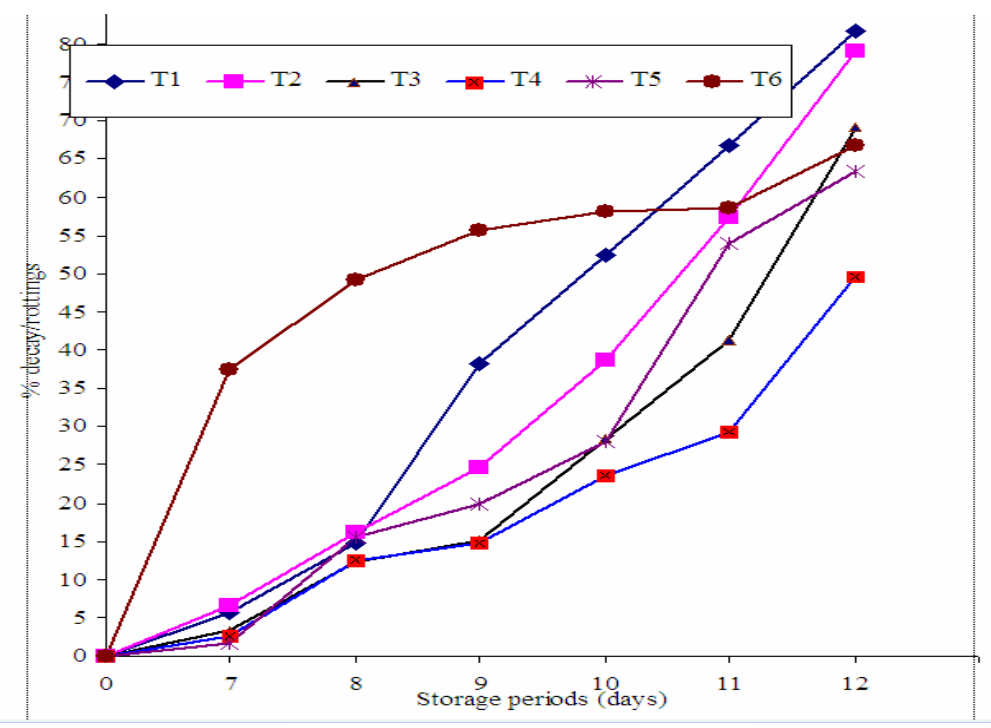

$\mathrm{T}_{1}=$ Zero perforation packet $\mathrm{T}_{2}=0.1 \%$ perforation packet, $\mathrm{T}_{3}=0.2 \%$ perforation packet, $\mathrm{T}_{4}=0.3 \%$ perforation packet, $\mathrm{T}_{5}=0.4 \%$ perforation packet, $\mathrm{T}_{6}=$ Control (without packet)

Fig.2 Effect of different packaging systems on the decay/rotting percent of green chili during storage.

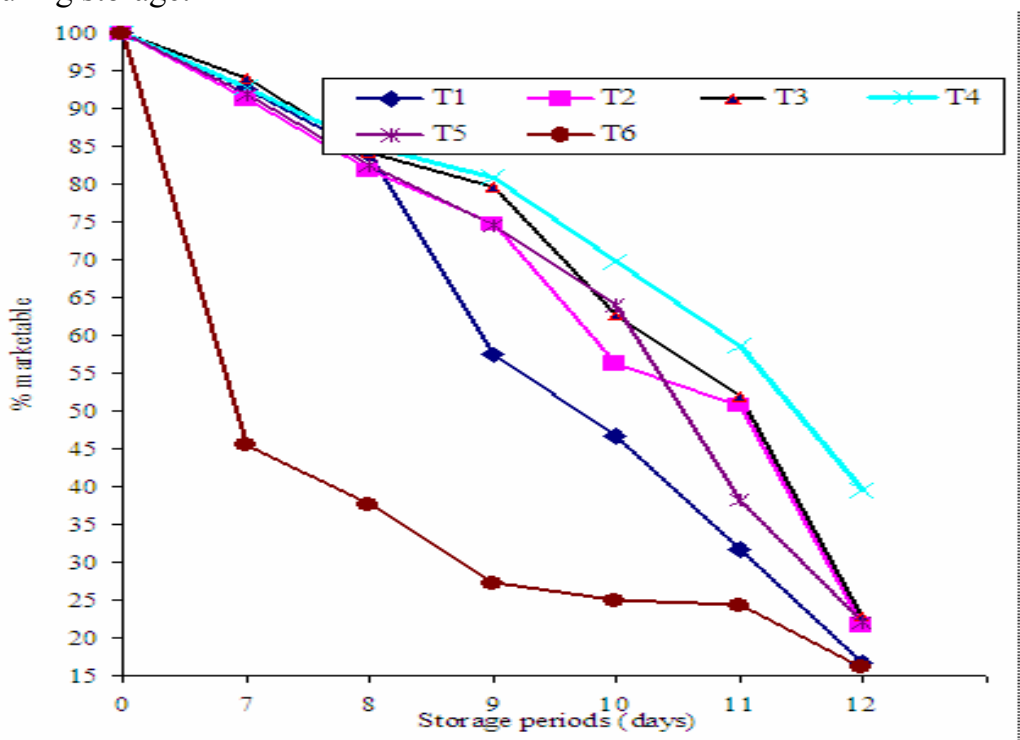

$\mathrm{T}_{1}=$ Zero perforation packet $\mathrm{T}_{2}=0.1 \%$ perforation packet, $\mathrm{T}_{3}=0.2 \%$ perforation packet, $\mathrm{T}_{4}=0.3 \%$ perforation packet, $\mathrm{T}_{5}=0.4 \%$ perforation packet, $\mathrm{T}_{6}=$ Control (without packet)

Fig.3. Effect of different packaging systems on the marketable quality of green chili during storage. 
A substantial reduction was noted in ascorbic acid (vitamin $C$ ) and $\beta$-carotene (vitamin A) contents of the chilies during storage. The reduction could be due to both oxidative and non-oxidative changes as described by Eskin (1979) and Land (1962). Such changes altered the colour of the chilies and lowered the nutritive value. Vitamin $C$ and $\beta$-carotene retention was highest $(83.67 \mathrm{mg} / 100 \mathrm{gm}, 54.287$ $\mu \mathrm{gm} / \mathrm{gm}$ ) in treatment $\mathrm{T}_{4}$ followed by $\mathrm{T}_{3}$, and $\mathrm{T}_{5}$, respectively, over the storage periods (Table $1 \& 2$ ). These chemical and nutritional compositions and changing behaviors of the stored chilies support to those found by Salunkhe (1991).

Table 1. Effect of packaging techniques on physico-chemical parameters of green chili during storage.

a) Vitamin C (mg/100g)

\begin{tabular}{c|c|c|c|c|c|c|c}
\hline \multirow{2}{*}{ Treatments } & \multicolumn{7}{|c}{ Vitamin-C content $(\mathrm{mg} / 100 \mathrm{~g})$ during storage } \\
\cline { 2 - 8 } & Initial & 7 days & 8 days & 9 days & 10 days & 11 days & 12 days \\
\hline $\mathrm{T}_{1}$ & & $136.87 \mathrm{a}$ & $95.84 \mathrm{c}$ & $91.66 \mathrm{~d}$ & $89.23 \mathrm{~b}$ & $73.23 \mathrm{e}$ & $66.33 \mathrm{c}$ \\
$\mathrm{T}_{2}$ & & $137.70 \mathrm{a}$ & $95.77 \mathrm{c}$ & $93.17 \mathrm{~b}$ & $89.74 \mathrm{~b}$ & $78.14 \mathrm{c}$ & $61.08 \mathrm{~d}$ \\
$\mathrm{~T}_{3}$ & 144.90 & $135.58 \mathrm{~b}$ & $95.70 \mathrm{c}$ & $92.19 \mathrm{c}$ & $87.56 \mathrm{~d}$ & $86.19 \mathrm{~b}$ & $75.11 \mathrm{~b}$ \\
$\mathrm{~T}_{4}$ & & $137.89 \mathrm{a}$ & $104.37 \mathrm{a}$ & $99.60 \mathrm{a}$ & $92.59 \mathrm{a}$ & $92.07 \mathrm{a}$ & $83.67 \mathrm{a}$ \\
$\mathrm{T}_{5}$ & $135.75 \mathrm{~b}$ & $97.44 \mathrm{~b}$ & $92.41 \mathrm{c}$ & $88.36 \mathrm{c}$ & $77.66 \mathrm{~d}$ & $61.67 \mathrm{~d}$ \\
$\mathrm{~T}_{6}$ & $126.86 \mathrm{c}$ & $80.28 \mathrm{~d}$ & $77.61 \mathrm{e}$ & $74.15 \mathrm{e}$ & $56.30 \mathrm{f}$ & $51.23 \mathrm{e}$ \\
\hline $\mathrm{CV}(\%)$ & 2.04 & 3.34 & 2.46 & 1.20 & 1.63 & 1.69 \\
Level of & $*$ & $*$ & $*$ & $*$ & $*$ & $*$ \\
significance & & $*$ & & & & & \\
\hline
\end{tabular}

b) $\beta$ - carotene $(\mu \mathrm{g} / \mathrm{g})$

\begin{tabular}{c|c|c|c|c|c|c|c}
\hline \multirow{2}{*}{ Treat-ment } & \multicolumn{7}{|c}{$\beta$ - carotene content $(\mu \mathrm{gm} / \mathrm{g})$ during Storage } \\
\cline { 2 - 8 } & Initial & 7 days & 8 days & 9 days & 10 days & 11 days & 12 days \\
\hline $\mathrm{T}_{1}$ & & $54.013 \mathrm{e}$ & $50.010 \mathrm{f}$ & $49.257 \mathrm{f}$ & $49.170 \mathrm{e}$ & $48.157 \mathrm{e}$ & $45.123 \mathrm{~d}$ \\
$\mathrm{~T}_{2}$ & & $60.227 \mathrm{a}$ & $55.247 \mathrm{~d}$ & $54.110 \mathrm{c}$ & $52.073 \mathrm{c}$ & $51.230 \mathrm{~d}$ & $51.053 \mathrm{c}$ \\
$\mathrm{T}_{3}$ & 78.75 & $59.173 \mathrm{~b}$ & $58.287 \mathrm{a}$ & $57.017 \mathrm{a}$ & $54.103 \mathrm{~b}$ & $53.057 \mathrm{~b}$ & $52.013 \mathrm{~b}$ \\
$\mathrm{~T}_{4}$ & & $57.137 \mathrm{c}$ & $57.030 \mathrm{~b}$ & $56.260 \mathrm{~b}$ & $56.017 \mathrm{a}$ & $55.060 \mathrm{a}$ & $54.287 \mathrm{a}$ \\
$\mathrm{T}_{5}$ & $57.083 \mathrm{c}$ & $56.197 \mathrm{c}$ & $53.190 \mathrm{~d}$ & $52.217 \mathrm{c}$ & $52.027 \mathrm{c}$ & $51.243 \mathrm{c}$ \\
$\mathrm{T}_{6}$ & $55.290 \mathrm{~d}$ & $54.257 \mathrm{e}$ & $52.140 \mathrm{e}$ & $51.277 \mathrm{~d}$ & $51.080 \mathrm{~d}$ & $51.007 \mathrm{c}$ \\
\hline $\mathrm{CV}(\%)$ & 1.83 & 1.92 & 1.96 & 1.98 & 1.98 & 2.05 \\
Level of & $*$ & $*$ & $*$ & $*$ & $*$ & $*$ \\
significance & $*$ & $*$ & & & & $*$ \\
\hline
\end{tabular}

$\mathrm{T}_{1}=$ Zero perforation packet $\mathrm{T}_{2}=0.1 \%$ perforation packet, $\mathrm{T}_{3}=0.2 \%$ perforation packet, $\mathrm{T}_{4}=0.3 \%$ perforation packet, $\mathrm{T}_{5}=0.4 \%$ perforation packet, $\mathrm{T}_{6}=$ Control (without packet) $*=$ Significant at $5 \%$ level of probability 


\section{Conclusion}

Green chili pre-treated with chlorine water and then packaging in $0.3 \%$ perforated polypropylene is the best for quality and shelf life for 10 days of storage at ambient temperature considering its physical appearance, marketable quality and change of physico-chemical parameters. Beyond this storage period, rotting and decay of the spices occurs rapidly, turn into red and shriveled and hence lose marketable quality.

\section{References}

Amiruzzaman M. 2000. Postharvest Technology/Management (vegetables). A consultancy report. AVRDC-USAID Bangladesh Project. Pp. 193.

Alejandra Rojas-Grau“ M, Gemma Oms-Oliu, Robert Soliva-Fortuny and Olga Martı'nBelloso 2009. The use of packaging techniques to maintain freshness in fresh-cut fruits and vegetables: a review. International Journal of Food Science and Technology 2009, 44, 875-889

AOAC 1984. Official Methods of Analysis. 14th edn. Association of Official Analytical Chemists, Arlington.

Badgujar, C.D., K.E. Lawande and P.N. Kale. 1987. Polythene packaging for increasing shelf life in brinjal fruits. Current Research Reporter. Mahatma Phule Agril. Univ. 3:2, 22-25; 2 ref.

BBS, 2009. Statistical Year Book of Bangladesh, Bangladesh Bureau of Statistics, Ministry of planning, Government of the Peoples Republic of Bangladesh.

Eskin, N.A.M. 1979. Plant pigments, flavours and textures. The Chemistry and Biochemistry of Selected Compounds. Academic Press, London.

Giraldo LF, Forero RA, Salazar CR and Torres R. 1977. The Effect of Packaging and Potassium Permanganate on the Storage of Tomatoes under Room Conditions. Ravista Inst. Collanbiano Agropecuario, 12 (4): 393-405. (Hort, Abstr. 49:4289)

Kader, A.A., D. Zagory and E.L. Kervel. 1989. Modified atmosphere packaging of fruits and vegetables. Critical Review in Food Science and Nutrition 28: 1-30.

Land, D.G. 1962. Stability of plant pigments. Advanced Food Research 2:50-56.

Ranganna S. 1986. Hand Book of Analysis and Quality Control for Fruits and Vegetables Products. Tata McGraw-Hill Publishing Company Limited. 
Salunkhe DK, Bolin HR and Reddy NR. 1991. Storage, processing and nutritional quality of fruits and vegetables ( $2^{\text {nd }}$ edition), CRC Press, Boston, USA.

Yang, S.F. and Hoffman, N.E. 1984. Ethylene biosynthesis and its regulation in higher plants. Annual Review of Plant Physiology 35:155-189. 